\title{
The piston and the pen: poetry and the Victorian industrial worker
}

\author{
Warton Lecture on English Poetry \\ delivered on 30 April 2019 \\ KIRSTIE BLAIR
}

Abstract: This article discusses some preliminary findings from the collaborative AHRC-funded research project 'Piston, Pen \& Press: Literary Cultures in the Industrial Workplace'. It uses examples of Scottish poets, and detailed study of two writers who were factory workers from the Bradford and Keighley area in Yorkshire, to argue that Victorian industrial workers were highly engaged with cultures of poetic production and deployed verse for a variety of political, social, and personal ends.

Keywords: Victorian, working-class, poetry, industry, Scotland, Yorkshire.

In the Victorian period, the small town of Stanley, in Perthshire, could boast at least three poets: John Campbell, born 1808, who published as 'Will Harrow' in the Dundee People's Journal; James Ferguson, born 1842, who published as 'Nisbet Noble', mostly in the People's Journal spin-off, the People's Friend; and John R. Reid, born 1849, who published as 'Pate Pleugh', mostly in the rival Dundee paper, the Weekly News. While there is no evidence that all three poets knew each other personally, Campbell and Reid were definitely acquainted, and it is extremely unlikely that Ferguson did not, at least, know of Campbell and Reid's poetry, and vice versa. The existence of three poets from a working-class background in the same locality, all publishing in the Dundee and Scottish popular press, is not at all surprising. As I explore in my most recent monograph (Blair 2019), every Scottish village expected to be able to produce at least one poet, and preferably more, and these poets were fostered and encouraged by the rise of the provincial newspaper press and its poetry columns. For the purpose of an investigation of literary cultures and the industrial worker, however, what matters about this cluster of Stanley poets is not their existence but their proximity to Stanley Mills, and the ways in which belonging to a mill town might have affected them as readers and writers. 
Built in the late 18th century, Stanley Mills expanded from the 1820s, and the village of Stanley expanded with them. Reid is unlikely to have worked in the mills: he was better educated than the other Stanley poets, and when he returned to settle in Stanley after a period working elsewhere, it was to assist in his father's 'coal and wood business' (Edwards 1881-1893, vol. 15: 166). There is also no hard evidence that Campbell was ever employed in Stanley Mills, though he had certainly turned his hand to mill work in Dundee, and may well have taken on occasional employment there during the many years he lived in Stanley. One of his poems, 'A Voice from Stanley Mills', published in the People's Journal in December 1863, deals specifically with the hard times caused by the closure of the mills in the 1860s, as a result of the Cotton Famine caused by the American Civil War:

The traffic on our grass-grown streets is thinning,

(A donkey on the verdure fondly browses),

And none are left, alas! to do the spinning,

Except the spiders in the empty houses.

(reprinted Blair 2016: 45)

These opening lines give an evocative sense of the emptiness and silence in Stanley when the mills are no longer running: nature is slowly taking over from industry, but this is not positive, as the 'merry' workers have been forced to leave the town for larger centres of employment. For Campbell, writing under his pseudonym 'Will Harrow', this is an unusually serious poem; he was best known for comic verse in Scots. The third poet, James Ferguson, definitely worked in the mills. He began his career in Stanley Mills as a young boy, before moving to Dundee and Glasgow in search of varied employment, as a shop-assistant, labourer, and clerk. In 1903, when his biography was recorded in Blairgowrie, Strathmore and Stormont Worthies, he was back in Stanley Mills, acting as 'warping foreman in the cotton mill he wrought in as a boy' (Dryerre 1903: 335). Though his career had seen him move up from manual labour to better paid and more respected work as clerk and foreman, and move in and out of industrial occupations, it ended by coming full circle.

Whether or not Reid and Campbell also worked for the mills, their work as poets was affected by their proximity to industry, in terms of access to reading materials and to associations, as well as in terms of possible mutual influence and inspiration. Campbell's biographer notes how Reid, for instance, 'delighted in' Campbell's company and 'emulated his Doric muse' (Fergusson 1897: 128). Stanley itself existed as a mill village: its first school, church, and shop were founded by company owners, and it owed its growth to its proximity to industry. It is unclear whether its library, run by a committee of village men from 1830 to 1847 as a subscribing library, and then re-opened as a free library (also run by committee) at some point in the 1850 s or 1860 s, was part sponsored or funded by the mill-owners, though it would not be 
surprising given the kinds of 'improving' philanthropy that mill-owners generally engaged in. Fergusson notes that 'Stanley has for many years enjoyed the benefits of a free library, and John Campbell was long one of its constant readers', and lists Campbell as a member of the library committee as an elderly man; Campbell also belonged to Stanley's Debating Society, and possibly to its Literary Society (Fergusson 1897: 124). It is probable that Reid did also, since such societies tended to attract members with literary inclinations. Certainly, for Campbell, whose education appears to have been severely limited, access to books and like-minded friends offered possibilities that he might not have had elsewhere. Of these three poets, only one wrote a poem directly about the mills. Ferguson's poetry largely consists of stirring historical verse about Scotland's past, and Reid's surviving verse does not - as far as I have discovered to date - mention Stanley. Yet they typify the kind of local writer-often mobile, moving in and out of industrial workplaces, linked to the popular newspaper press, publishing under a pseudonym - that we are most likely to find in mill towns or in the mills themselves.

This essay uses some of the initial findings of this project, which will no doubt be supplemented as our collective research expands, to argue that poetical production was important for many Victorian industrial workers, and that their surviving poems can give us insight into some of the factors that shaped their working lives. On the 'Piston, Pen \& Press' project, we attempt to trace the contributions that industrial workers made to Victorian literature, and consider whether the appearance in print of local poets like Reid, Campbell, and Ferguson can be associated with the rise of industrial workplaces, which brought people together in close proximity, and tended to sponsor the kinds of associational culture, and competitiveness, that might lead to literary production. The first half of this essay additionally serves as a reflection on the issues and difficulties that I, and other members of the project team, have encountered as we try to recover this body of literature. As distinct from the talk delivered as the Warton Lecture, I have chosen to focus the second half of this essay in-depth on two individuals discussed in that talk, rather than moving between a larger number of examples but with brief attention to each. My arguments throughout rest on the foundational scholarship on working-class poetic cultures produced by Martha Vicinus (1974), Brian Maidment (1987), Florence Boos (2008), Michael Sanders (2009) (co-investigator on this project), Andrew Hobbs (2012, 2019), and others, and on the recent findings of related projects, such as Simon Rennie's 'The Poetry of the Cotton Famine'. ${ }^{1}$ As these scholars have demonstrated, and as I argue myself elsewhere, working-class poets in Scotland and the North of England wrote poetry for

${ }^{1}$ See 'The Poetry of the Cotton Famine': http://cottonfaminepoetry.exeter.ac.uk (consulted 2 August 2019). 
many reasons. They might intend to demonstrate their intelligence and sensibility, showing off cultural capital in lieu of the possession of much monetary capital. They frequently produced verse to celebrate or commemorate a particular occasiondeaths, births, marriages, and special events both local and national. Their poems were often activist, in the sense of advocating for change on a particular social or political issue. And they used poetry to create and share a sense of community, both by writing on local topics and in local dialect, and by directly naming fellow poets and fellow citizens of their locality.

All these statements are true of poets who were industrial workers in the Victorian period, but they would be equally true of working-class poets from an era before the factories and railways, of Robert Burns, for instance, or John Clare. The difference between pre-industrial and post-industrial working poets - or between a Victorian agricultural labourer writing poetry and a Victorian power-loom weaver-is not, I would suggest, a difference of intent. It is rather a difference of scale and opportunity, a difference evident both in content, and in the means of circulation and production of poetry. There are, for instance, many railway poets in our records. But prior to the 1820s, it was not possible to be a railway poet, since the railways did not exist. Poems on engine-driving, on signalling, on railway accidents and disasters, on the life of a railway navvy, may draw on older genres, but their content is fundamentally new and a product of industrial development. And if they appeared in a periodical produced by a railway company, they were also appearing in a new genre of publication.

Similarly, poems on factory outings, a genre briefly mentioned below, did not exist before the growth of the factories (and in some cases, options for railway transport) made mass outings for employees a common practice. Placing ever-larger numbers of people in the same physical space for work, as became standard in factories, mills, and in the mining industry, also created opportunities for associations and societies to arise. This is evident in trades unions and cooperative societies, which themselves were strongly invested in promoting reading and writing, and in the broader mutual improvement movement, but also in the formation of amateur literary and dramatic societies, for instance, or in the production of workers' newspapers. Many such societies sponsored small or larger scale reading rooms and libraries. It was not until the repeal of the Stamp Duty and paper duties around mid-century, moreover, that a popular press directed towards industrial workers in specific professions, as opposed to the earlier radical press, arose. Alongside the local press, which was usually sympathetic towards working-class writers, newspapers such as the Cotton Factory Times, the Yorkshire Factory Times, or The Miner and Workmen's Advocate specifically catered to new industrial workers. These newspapers tended to have political aims or union affiliations, to various degrees, and their efforts to encourage readers to see themselves 
as contributors, not simply consumers, fed into the belief that more highly educated and literate workers would be more equipped to agitate for their rights.

Before turning to a case study of some writers, readers, and associations discovered through research into the Yorkshire textile industries, I want to use four examples to highlight some of the complexities involved in recovering and assessing poetry by industrial workers from this period. The first example relates to a key problem in recovering working-class poetry more broadly: its deliberate lack of originality. As noted above in relation to the Stanley poets, not all identified worker-poets wrote about their work or their workplace. Indeed, poems concerned with industrial labour are relatively rare in the output of working-class poets, in relation to the numerous poems on core themes welcomed by the newspaper press and enjoyed by readers: love poems, seasonal poetry, nature poetry, religious and moralistic poetry, elegies, and poems about childhood and children. 'Winter', a poem published in the Jedburgh Gazette and Border Courier on 15 January 1881, signed 'Effie' (pseudonym of Effie Williamson, a Borders millworker) is typical. It opens:

What painter has been at my window

In the silent hours of night

Doing lovelier work in the darkness

Than mortals could do in the light?

(Williamson 1881: 3)

The poem describes the beauties of winter, before turning to a religious moral, highlighting the Christian obligation for the rich to take care of the poor during the season that 'falls like a load of care/On the aged poor and needy'. Though this does highlight the social conscience of a poem which initially seems simply like a description of nature's beauties, it is a familiar moral in a poem on winter's cold. Everything about these verses is designedly recognisable, both from the long tradition of seasonal poems in English, and the newer tradition of publishing newspaper poems that reflected on the current season or weather (so that a 'Winter' poem is usually published in January, as here). The form, and the rhymes, are predictable: we know that 'night' will lead to 'light', or 'cold', in stanza three, with 'old.' Williamson is important, given the relatively small number of named and identified working-class women poets from this period, and the even smaller cohort of those poets who were industrial workers. Yet almost all her identified poems, in the newspapers and in her collection, are in a similar vein; moral, Christian, and often concerned with nature and related themes. Whatever her experiences of industrial work may have been, these are not reflected in her publications, which contain no 'factory' poems. This is not in any way surprising. A stigma was still attached to women working in industry, and indeed to women writers more broadly, so if Williamson wanted to see her work in the newspaper press, she had to conform, carefully, to the accepted standards for women's 
periodical poetry. The fact that she wrote poetry, and that she was part of an active network of poets in the region, is important for our understanding of Victorian literary production, yet for a 21 st-century audience, her poetry itself holds little appeal, since it neither gives us insight into the lived experience of industrial workers, nor stands up to sustained literary analysis of form and content.

John Hogg, of Lanarkshire, represents a similar issue in relation to the majority of his poems, and also in relation to the identification of 'industrial' poets. The title of his one posthumous collection, A Village Poet and His Poems (1910), gives no indication that he worked across at least two core industrial professions. Trained as a handloom weaver, he was employed by the Caledonian Railway Company for a period, and then as a pithead labourer for the Nitshill and Lesmahagow Coal Company. This last is particularly significant, because although many 'mining' poets have been identified, most worked as colliers below ground, rather than on the surface. Hogg's different professions are mentioned in the ninth volume of D. H. Edwards' Modern Scottish Poets (1881-1893, vol. 9: 164) and in the biography that opens $A$ Village Poet. But if he had not rated inclusion in Edwards's anthologies, there would be no other indication that his collection was significant for a study of industrial workers. And within Hogg's collection, there is only one poem that directly speaks of industrial labour, very briefly, 'Epistle to James Erskine.' Hogg's 'Epistle' recalls walking to work with Erskine in the winter snow, and then reminisces:

\author{
An' syne we wrocht a ten-hoors day \\ Emptying hutches owre the brae. \\ When things gaed richt the time flew by \\ Fu' cheery, Jim, wi' you an' I; \\ But oh, dear me, if ocht gaed wrang, \\ The boss cam' oot wi' sic a bang. \\ He drilled us baith like raw dragoons \\ An' ca'd us useless weaver loons.
}

(Hogg 1910: 59)

The fact that their unidentified workplace is the pithead is shown by one word, 'hutches', which refers to the containers for coal or ironstone brought up from the pit. Without this one word - or this one line - this would still be a poem by an industrial worker, but it would not so clearly be a poem about a key industrial occupation. These lines are significant in offering a commentary on both the difficulties (long hours, an angry boss) and pleasures (companionship and chat) of surface work at the mines. They are also particularly important because they emphasise that these pithead labourers - a position that was not highly regarded in the hierarchy of mine labour, and often went to older or more infirm men-were former handloom weavers, and were criticised as such. Handloom weaving, in sharp decline from the 1820s onwards due to the rise of the factories, tended to be romanticised as a profession, including by 
those who had started their careers practising it. This poem demonstrates, in one economical passage, the necessity for weavers to find other employment, and the issues they might face. And it also demonstrates that detailed reading of anthologies and collections is essential in order to find the one passage, out of all the author's poems, that speaks directly about their participation in industry.

The epistle form is especially valuable in locating poets within particular professions, because, although authenticity is always in question in the literary productions of workers, the convention is that epistle poems should discuss the writer's 'real life' and mention where and when the epistle is being written, in an informal and conversational style. Hence this genre often speaks more directly about the writer's life and work than most other common genres of the period. In some cases, such as the poems of Henry McAnally of Newcastle upon Tyne (1866), it is only through an epistle poem, inviting a friend to visit him at his place of work, that we can tentatively locate him as an employee of the ironworks in Walker. 'Epistle' poems, though often published in the local press, are also represented as personal communications. But many of the poems that can be used to identify authors as industrial workers were designed for public, communal recitation. Occasional verse, or verse designed to respond to, celebrate, or commemorate a particular event, is one of the most useful genres in terms of tracking workers' engagement with verse, because poetry was frequently performed at workplace events. Yet the question of authenticity is also vital here, and such poems may have a more complex genesis than their self-presentation, as productions by a worker in the industry described, would suggest.

One such poem is Ayrshire and Glasgow poet John Parker's 'To Peter Robertson Esq., Engineer: Late Manager of the Glasgow and South Western Railway Workshops, Cook St, Glasgow', published in his poetry collection from 1859. Typically of such poetry, it praises both the individual being celebrated, and the industry in which he and his fellow employees work:

The iron king, wi' royal power,

Proclaims thy genius every hour;

As lightning flies with vivid speed;

Thy skill propels the fiery steed.

Ah, Robertson, thy lofty mind,

Thy genius great, with art combin'd,

Has won for thee a nobler name

Than tyrants ever dare to claim.

(Parker 1859: 59-60)

The poem celebrates Robertson as enlightened, intelligent, and interested in elevating 'thy brother man'; many such poems have a similar subtext, which suggests that other employers may be 'tyrants', but the particular employer addressed is one of 
the better ones. They thus serve the purpose of flattering the employer or the company while offering positive reinforcement for good behaviour towards the workforce. But this poem also highlights how misleading occasional verse can be. Had we found it in the newspaper press, it would be plausible to assume that Parker 'belonged' to the workplace mentioned here and was a railway employee. This may have been the case at some earlier or later point, though internal evidence in his one collection strongly suggests that he worked in a carpet-weaving factory. Moreover, in volume publication, this poem came with a footnote:

The foregoing poem was composed for an occasion, in favour of the above-named gentleman, who was about to leave the Ayrshire Depot, and was to have been sung by a nephew of the author's, at a festival which was to be given by the works in favour of said gentleman. (Parker 1859: 60)

As the footnote goes on to inform us, Parker's nephew had left for Canada before attending this festival, and had since died overseas. This note raises a number of questions. Did Parker write these verses for his nephew, without any connection with the railway works or Peter Robertson himself? If so, was the original intent that Parker's nephew would pass the poem off as his own composition, given that it might gain him credit with his employers? And would Parker have reprinted this poem, if his nephew had still been alive and working in Glasgow? As often in working-class poetry, what might seem to give insight into a poet's actual working life or circumstances turns out to be constructed or fictional. Parker was an industrial worker, but probably not working for the Glasgow and Southwestern Railway at the point when he composed this poem. In other examples, the fictional quality of an occasional poem extends to the author's persona. One Bradford broadside on the controversial 18901891 strike at Manningham Mills, a strike which was foundational in the formation of the Labour Party (Salveson 2012: 59-60) was signed 'To t'Manningham Strikers, by One of Thersen', and written in dialect, opening 'Ah'm fairly stalled o't'strike lads.' Though its representation of a worker who is anti-strike and anti-trades union doubtless seemed suspicious at the time, it is unlikely that the striking workers could have known that this poem was written by one of the mill managers' wives, Annie Watson. Her authorship was only identified through the work of local historians in tracing private correspondence relating to the Watson family. ${ }^{2}$

These examples highlight some of the key issues in identifying and locating industrial workers who wrote poetry, and in assessing the poems they wrote; including

${ }^{2}$ The evidence of Watson's authorship consists of a letter from the other mill manager to the owner, Samuel Lister, found by Bradford Industrial Museum volunteer Derek Barker in 2011. A copy of the letter is in the 'Mrs Anne Watson' archive, West Yorkshire Archive Service, Bradford Central Library, WYB530. 
questions of aesthetics and authenticity, as well as problems in the retrieval and recovery of the poems themselves and the contexts in which they were created. But they also show us the liveliness of a culture of poetic production in and around industrial workplaces, and its investment in various genres, forms, and modes of publication, distribution, and performance. In the remainder of this essay, I will turn to two examples of poets from the Bradford area, Abraham Wildman and Joshua Wood, in order to demonstrate the intersection of poetic production and the industrial workplace with politics, with the culture of mutual improvement, and with associational culture more broadly. Both writers operated in roughly the same period, though they were from different generations. They also differ in that Wildman had a local reputation as a poet and was remembered by regional anthologisers, like Charles Forshaw, whereas it is unclear whether Wood ever published any of his poems, and his name is not mentioned in any local histories or anthologies. Wildman and Wood, unusually, left fairly extensive manuscript material, but deciphering its relationship to contemporary events, and ascertaining whether it was ever published or circulated, is not easy, largely because these manuscript poems would almost certainly have been published in local newspapers or as broadsides, which may not have survived.

West Yorkshire, including Bradford, Halifax, Keighley, and surroundings, had a particularly lively culture of societies and associations, fostered in part by dissenting religion and by radical politics: this area was a centre for Chartism in the 1840s. From the 1830 s to the 1890 s and beyond, fast-growing industrial towns such as Keighley and Bradford boasted multiple mutual improvement associations, literary associations, working men's institutes, and reading rooms and libraries, besides large and important mechanics institutes. Bradford's Mechanics Institute library, for instance, went from 800 volumes in 1833 to over 44,000 in 1890 (Scruton 1895: 87) Keighley and Bradford, besides their local newspapers, also supported various small-scale, and often short-lived, periodicals, such as the Keighley Visitor, The Keighley Cooperative Bee, and the Bradfordian. Some of this lively culture of self-improvement could be said to arise from the workers themselves, though much was also sponsored by better off citizens. As Jack Reynolds, historian of Bradford in this period, has argued, the programme of 'improvement' for the town and its citizens, while condescending in some respects, 'offered outlets for working-class ambition and hope - the prospects of economic and social mobility and at another level, essential tools in the struggle for political democracy' (Reynolds 1983: 153). By 'the struggle for political democracy', Reynolds means that respectable working men (and to a lesser degree, women), whose respectability was evident through their involvement in mutual improvement societies, temperance societies, churches, and indeed literary societies and forms of literary culture, were more likely to be viewed positively as candidates for enfranchisement in the Reform Acts of 1867 and 1884, and eventually 1918. 
Abraham Wildman was born in Keighley either in 1803, according to his newspaper obituary and to Forshaw (1888: 119), or in 1804 or 1806, according to the census records for 1851 and 1841. What we know of Wildman's career, largely from the obituary by his friend, bookseller and publisher Abraham Holroyd, is ambiguous, but seems to suggest a reversal of the more common upward trajectory experienced by intelligent working-class writers. In the 1820 s and 1830 s, Wildman appears to have been in the textile business for himself. In 1841, he is listed as 'independent' in the census. Holroyd suggests that his business failed around this time, and by 1851 he was a warehouseman in Bradford, then 'a woolsorter at Messrs Wood and Walkers' (Holroyd 1870: 7). At least one of his daughters worked as a factory weaver. By the late 1860s, after the death of his wife, Wildman was destitute. Holroyd apparently spoke to millowner Titus Salt about him, with the result that Wildman was offered a place in the new Saltaire almshouses, where he died in early 1870. His career therefore exemplifies the complexities of the term 'industrial worker': he certainly worked in industry, and wool-sorting was not among the most prestigious or better paid forms of factory labour, but at least for part of his career, he also appears to have been an employer rather than an employee.

In addition to his regular employment, Wildman had another career (possibly attracting some income) as a political advocate for the cause of factory workers, and it is in this capacity that he wrote most of his poems. In the 1830s, he was an activist for the 'Ten Hours Bill', which sought to reduce working hours: 'He became secretary for the district, organised meetings, got up petitions to the Lords and House of Commons, and corresponded generally with all the friends of the movement' (Holroyd 1870: 7). In one court case from 1835, where two young women were accused of leaving their factory shift early without cause, then an offence which could result in prosecution by the employer, Wildman defended them on the grounds of what we would now call sexual harassment from the overlooker, whose 'obscene and filthy language', Wildman declared, had become 'unsupportable' and left them no choice but to walk out (Holroyd 1870: 7) He was also active in the local agitation around the plight of the wool-combers, 'the most deplorably exploited of all the textile workers' in the mid-1840s, when their low wages and dismal living conditions were taken up as a cause by Chartist George White (Reynolds 1983: 125)

While Wildman's early collection, Miscellaneous Poems (1829), largely contains pastoral verse and other poems on typical themes of the day, his newspaper poetry, and the manuscript poems in his notebook, are highly politicised. 'The Lay of the Woolcomber' (also titled in manuscript 'The Wool-comber's Song'), for instance, published in the Bradford Observer on 19 June 1845, focuses on the terrible domestic conditions of wool-combing. Wool-combing was a profession then carried out in the home, which involved keeping a smoky charcoal stove burning night and day: 
The sweet breath of morning ne'er enters my dwelling,

To clear the old fumes from the damp-colour'd ceiling,

Which constantly oozing,

Keep soul—body dozing

In this dismal hole

What ever the weather

We're huddled together

And breathe the slow poison arising from coal.

(Wildman 1845: 7)

In the manuscript version, Wildman originally wrote 'sweet breeze' for 'sweet breath', 'colourless ceiling' for 'damp-colour'd ceiling' and 'constantly fuming' for 'constantly oozing' (Wildman, 'Waste Book': 125). His process of revision suggests improving the sense of the poem (it is more likely that a ceiling will 'ooze' than 'fume'), considering the language carefully ('fuming' was a repetition of 'fumes' in line two of the stanza), and introducing more realistic and unpleasant detail in the combination of smoky fumes and damp oozing cellar. Substituting 'breath' for 'breeze' also draws attention to one of the central points of this poem, the breathing problems and lung disease caused by smoke and by wool fibres. The next stanza continues:

Six children and wife, with self, number eight;

A bed of deal shavings our couch for the night;

We rise in the morning,

The same rags adorning

To toil at the comb;

Like quarry-men digging

We're smatching and jigging

One room is our workshop, our cookshop, and home.

(Wildman 1845: 7)

The italics are added in the published version. Wildman's poem highlights industrial pollution on the small scale, emphasising its impact on the family in the shift from ' $\mathrm{I}$ ' in the opening stanza to 'we' in subsequent stanzas. Wool-combers suffered through the rise of machinery and consequent drop in wages, but in the long term this profession greatly benefited from larger scale industrial workplaces and mechanisation, which considerably improved working conditions. This poem is aligned with campaigners who thought that wool-combers should be employed in larger scale workshops, as opposed to working from home. Wildman was also exercised about the terrible quality of housing for the poor in the Bradford and Keighley area, writing and rewriting a long draft manuscript poem on 'The Homes of the Poor', and here he also focuses on the misery of an impoverished family crammed into one room. The detail about their lack of furniture and clean clothing shows how little they are paid for wool-combing. Technical terms like 'smatching and jigging' indicate that the author intimately knows the labour he is describing. 
This poem is political in the context of agitation over the plight of people in this profession, though it is much less overtly radical than other poems in Wildman's manuscript notebooks, which, without explicitly referencing Chartism, use language familiar from Chartist verse. In 'Lines on the Death of Jonathan White' (a 90 year old whose death in the workhouse had been reported in the Yorkshire press), for instance, Wildman wrote, on the Poor Law:

Our Sires who fought for Liberty

Did never mean their children Slaves

No- no-we will ourselves be free

We swear the same above their graves

The Sword of Freedom we will draw

And fight against this cursed Law.

(Wildman, 'Waste Book': 84)

In one of the versions of a draft poem opening 'Bread, bread is still the cry'-thus possibly an anti-Corn Law poem-two typical stanzas run:

Tyrants tremble - now's the hour

Must we sink beneath your power

No our might and main we draw

Never will we meet your law

**

Now no longer we will bear it

By our [?] both we swear it

Never-never more will we

Bear your chains of Tyranny

(Wildman, 'Waste Book': 93)

This language of slavery, tyranny, freedom, and liberty, particularly when these concepts are capitalised, is typical of radical verse in the first four decades of the 19th century. Both these poems could be easily set to familiar tunes, and it is entirely plausible that they were intended to be performed or sung at meetings, or were circulated in broadside form, rather than intended for newspaper publication (editors seeking a wide local readership tended to be wary of politically inflammatory poems). Such poetry feeds into the threat of Chartist revolution in Bradford and Keighley, very real to the authorities in the late 1840s, when Chartists were 'drilling openly in the streets' and tens of thousands were attending local meetings advocating for rebellion. Wildman's 'The Lay of the Woolcomber' is signed 'Manchester Road', naming a stronghold of Bradford Chartism: James Wilkinson, a tailor and poet, also named Wildman as one of 'The Poets of Manchester Road' in an 1849 poem, along with Stephen Fawcett, another politically inclined newspaper poet. If not directly identifying Wildman as a Chartist, this at the very least situates him with the radical working class.

Manuscript sources are relatively scarce in the study of workers and their writings, since few survived to the 21 st century. The survival of Wildman's manuscript drafts 
shows how much more strongly worded his poetry was in private, or perhaps when intended for circulation only amongst a sympathetic community, than in his published volume. That these notebooks and ledgers also contain accounts, letters, and notes relating to his or others' non-poetic work show the extent to which poetry composition could be interwoven into working lives. Joshua Wood, not dissimilarly, left a scrapbook and large-sized notebook full of his own draft poems, as well as newspaper poems and letters pasted into the scrapbook. The ostensible purpose of these notebooks appears to have been as account books for Low Moor Working Men's Institute, of which Wood was Secretary, and the second notebook includes a printed report on the Institute from 1873. But the accounts are interspersed with handwritten verse, with some poems existing in several revisions or variations. Wood appears to have been a founding member of this Working Men's Institute and one of its champions, and internal evidence from the notebooks also places him as a member of a formal or informal debating and discussion society, which met at Laycock's Temperance Hall in Bradford around the 1860 s or 1870 s and appears to have primarily involved men in artisanal and industrial occupations. ${ }^{3}$ The most probable Joshua Wood in the census records was born in 1826 in Halifax, and is listed in the 1871 and 1881 census records as a warp dresser, married with four children (his two eldest daughters were weavers) and living at Hill Top, North Bierley. This fits with the Joshua Wood of these notebooks, which place him at 'Hill Top, Low Moor'-the same area-and contain a poem about the 1876 local elections in North Bierley. The notebooks suggest that Wood was an overlooker, a relatively high-status worker within the textile industry, though this is not incompatible with working as a warp-dresser at some points, since overlookers were often promoted from the factory floor.

Wood is interesting because his notebook poems, like Wildman's, read as though written for performance, rather than as either entirely private works, or draft works planned for publication. They serve to emphasise how important associational culture was for verse composition. One poem in Wood's notebook, for instance, existing in more than one draft and possibly intended to be read at a meeting, reflects on his membership of the club with which he was involved:

Of the working men's club, I'm member

I joined, when first it began

Social friendship, to engender

In common, with my fellow man

\footnotetext{
${ }^{3}$ The notebooks list the names of the some of the attendees at these meetings. Of those that can be tentatively located in census records, professions include handloom weaver, stone mason, stationer, and master tailor.
} 
I've a taste, for newspaper reading

Scanning, the events of the day

Deep thinking, I cannot succeed in

That's work for great minds to display

And books too, such a pleasure impart

With their ever, bounteous flow

Of instruction on science and art

On studious minds to bestow

Homely philosophy I treasure

Poetry simple and pure

I love to peruse at my liesure

Or any good literiture

(Wood undated: n.p.)

Wood's spelling and punctuation suggest that he is relatively uneducated, and that he is still learning the rules for writing a poem in correct English, and in a credible style (what newspaper editors liked to call a 'smooth' style), with due attention to the harmonious integration of rhyme and rhythm, not quite achieved here. This is, in effect, a poem about the importance of engaging with literary culture, which also reflects on that engagement in its form. Varied activities might take place in a working man's institute, but for Wood, the most important involve reading - such institutes, including Low Moor, usually had a reading room, which would subscribe to newspapers and periodicals and supply a small collection of books. The poem may have been intended as a recruiting tool, to convince new members to join, or may have been read at a meeting of existing members, as a means of sharing their commitment to self-improvement. Further draft poems expand upon the foundation of this institute:

I'll tell you a little secret about some working men.

But do not say a word at least to noan o'them

They met one neet in a chamber over a joiners shop

To talk about an institute being formed at Hill Top

A committee were appointed to see what could be done

And they set to work in earnest I am sure every one

For rooms were secured a place where they could meet

Bud hah to get um furnish'd noan o um could see it

First they thought they would borrow $t$ brass and waited on a friend

To see if he knew someone who had ten pound to lend

Well says he I can get yo it but wodnt it be as well

To try $t$ neighbouring gentlemen I'll give five bob mesel

This poem represents the determination of a group of 'working men' to improve themselves and their community; Wood is keen to stress that the genesis of this 
institute comes from them, and that they do not ask for charity from better off people in the area until they are advised to do so. The slips into local dialect in this account are especially intriguing. Is Wood setting out to write in dialect, because it fits the subject matter, and consciously using non-standard English in poetry, as many Bradford poets did for narrative, humorous verse? Or is he writing as he would have spoken, without correcting himself?

It is extremely unlikely that Wood would have considered himself 'a poet'. Writing verse about his interests, which also included temperance, local elections, and other issues, and working-class life and leisure, was likely something he did to entertain his friends and fellow institute and society members, as well as part of his programme of self-culture and self-improvement. As with many poems by industrial workers, this is not well-written poetry: unlike Wildman, Wood might have struggled to reach the standards required for publication in the newspaper poetry columns. But these notebooks, which only survive because Wood's family kept them and passed them on the archives, show how much a Bradford industrial worker enjoyed composing poetry, and the extent to which he spent what was surely his limited leisure time in this pursuit.

The richness of such archival materials show much remains to be uncovered about the ways in which industrial workers used verse, strategically and for various ends, and the ways in which they found pleasure and profit in it. Though middle-class patrons, readers, and editors tended to represent poets from industrial occupations (like Joseph Skipsey, miner, or Alexander Smith, pattern-maker) as rare and unusual, this was far from the case. It would, rather, have been relatively unusual for a large workplace to have no employees who could produce a reasonable set of verses, and many workplaces could boast one or more published poets. Wildman, Wood, and the other writers discussed in this essay, represent a very small sample of the industrial poets already located during the first year of the 'Piston, Pen \& Press' project. Writing in a period from which few workers' oral or written histories survive, their poems can give an insight into their working conditions and practices, their leisure activities, their friendships and communities, and their involvement with and investment in literature and culture.

\section{REFERENCES}

Blair, K. (ed.) (2016), The Poets of the People's Journal: Newspaper Poetry in Victorian Scotland (Glasgow, Association for Scottish Literary Studies).

Blair, K. 2019, Working Verse in Victorian Scotland: Poetry, Press, Community (Oxford, Oxford University Press). https://doi.org/10.1093/oso/9780198843795.001.0001 
Boos, F. (ed.) (2008), Working-class Women Poets in Victorian Britain: An Anthology (Peterborough, ON, Broadview).

Dryerre, H. (1903), Blairgowrie, Stormont, and Strathmore Worthies (Blairgowrie, Henry Dryerre).

Edwards, D. H. (ed.) (1881-1893), Modern Scottish Poets, 15 volumes (Brechin, D. H. Edwards).

Fergusson, R. M. (1897), A Village Poet (Paisley, Alexander Gardner).

Forshaw, C. F. (1888), Yorkshire Poets Past and Present, volume 1 (Bradford, T. Brown).

Hobbs, A. (2012), 'Five Million Poems, or the Local Press as Poetry Publisher, 1800-1900', Victorian Periodicals Review, 45: 488-92. https://doi.org/10.1353/vpr.2012.0044

Hobbs, A. (2019), A Fleet Street in Every Town: The Provincial Press in England, 1855-1900 (Cambridge, Open Books Publishing). https://doi.org/10.11647/OBP.0152

Hogg, J. (1910), A Village Poet and His Poems (Glasgow, R. Forsyth).

Holroyd, A. (1870), 'Abraham Wildman', Bradford Observer, 24 March: 7.

McAnally, H. (1866), Poetical Works (Newcastle upon Tyne, H. Savage).

Maidment, B. (1987), The Poorhouse Fugitives: Self-taught Poets and Poetry in Victorian Britain (Manchester, Carcanet).

Parker, J. (1859), Miscellaneous Poems (Glasgow, Spittal and Alison).

Reynolds, J. (1983), The Great Paternalist: Titus Salt and the Growth of Nineteenth-century Bradford (London, Maurice Temple Smith [University of Bradford]).

Salveson, P. (2012), Socialism With a Northern Accent: Radical Traditions for Modern Times (London, Lawrence \& Wishart).

Sanders, M. (2009), The Poetry of Chartism (Cambridge, Cambridge University Press). https://doi.org/10.1017/CBO9780511576195

Scruton, W. (1985, reprint from 1891), Pen and Pencil Pictures of Old Bradford (Otley, Smith Settle).

'To T’Manningham Strikers' (1891), Unsigned broadside, West Yorkshire Archive Service, Bradford Central Library, WYB530.

Vicinus, M. (1974), The Industrial Muse: A Study of Nineteenth-century British Working-class Literature (London, Croom Helm).

Wildman, A., Manuscript notebook, undated, Keighley Library, BK185/2.

Wildman, A. (1829), Miscellaneous Poems (London, Simpkin and Marshall).

Wildman, A., 'Waste Book commenced January 1 1834', Keighley Library, BK185/1.

Wildman, A. (1845), 'The Wool-comber's Song', Bradford Observer, 19 June: 7.

Wilkinson, J. (1849), The Odsall Rural Party, and the Poets of Manchester Road (Bradford, John Dale).

Williamson, E. (1881), 'Winter', Jedburgh Gazette and Border Courier, 15 January: 3.

Wood, J. (undated), 'Poetry by Joshua Wood', Undated scrapbook and notebook. Rollinson Family of Bradford Collection, West Yorkshire Archive Service, Bradford Central Library, 18D91/2/3.

Note on the author: Kirstie Blair is the author of three monographs and a wide variety of other publications on Victorian poetry and poetics: her most recent book is Working Verse in Victorian Scotland: Poetry, Press, Community (Oxford University Press, 2019). She is the Principal Investigator on the AHRC project 'Piston, Pen \& Press: Literary Cultures in the Industrial Workplace' (2018-2021), and the Director of the Scottish Centre for Victorian and Neo-Victorian Studies (SCVS). kirstie.blair@strath.ac.uk 
To cite the article: Kirstie Blair (2019), 'The piston and the pen: Poetry and the Victorian industrial worker', Journal of the British Academy, 7: 123-139.

DOI https://doi.org/10.5871/jba/007.123

This article is licensed under a

Creative Commons Attribution-NonCommercial-NoDerivatives 4.0 International License.

Journal of the British Academy (ISSN 2052-7217) is published by

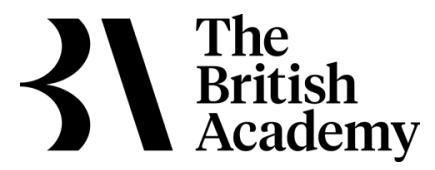

10-11 Carlton House Terrace, London, SW1Y 5AH

www.thebritishacademy.ac.uk 
